\title{
Contract of Sale of Agricultural Land under the Provisions of the Civil Code
}

\author{
Irena Lavdari \\ The European University of Tirana, Faculty of Law, Doctoral candidate \\ irenalavdari@yahoo.com
}

\section{Doi:10.5901/ajis.2016.v5n1p277}

\begin{abstract}
The contract is the most widespread juristic instrument in the civil circulation of a market economy. The main juristic and commercial acts of different subjects in the conditions of the market economy are embodied in a contract. The contract is one of the ways how to gain ownership and other real rights by being an instrument of circulation of the goods realized by the contracts of sales, donation, exchange etc. The sales contract of sales was recognized as such since the times of the Roman Right and it continued to be elaborated until the present days. In its early origin, the most ancient form of sales consisted in the exchange of goods with other goods. The sales contract used to be also one of the most common agreement in the Albanian traditional right. The contracts which were more diligently protected and better known, were related to the sales. According to the traditional right, object of the sales contract could be the mobile and immobile goods. The definition of the contract according to the present Albanian legislation, is provided in the Civil Code in the article 659, according which the contract is a juristic act through which one or more parties create, change or terminate a juristic relation. The contract is one of the forms of gaining the ownership and other real rights by being an instrument for the circulation of goods realized by the contracts of sales, donation, exchange etc. The contract is also one of the sources of obligation, in other words, an instrument through which one gains the right to the others 'obligations. Depending on the sales object, the contract has some specifics. The sale is a mutual beneficial contract. It is consensual, which means valid from the moment of achievement of the parties 'agreement. In some cases, the law demands that the sales contract is formal and registered. The contract of sale in many cases has caused many problems which stand at the roots of conflicts that should be dealt with and that require solutions in different legal ways. Therefore, it is important to study and treat these contracts and the problems that associated to them with regard to the institutions of the right and the national and/or international transactions.
\end{abstract}

Keywords: contract, party, sale, will, ownership transfer, rights, obligations.

\section{Introduction}

During the past three decades, international commerce - consequently the Albanian one - has increased considerably. This expansion was undoubtedly urged by the formation of regions, political and economical units and the removal of legal boundaries between different countries. On one hand, the initiatives and developments in technology, information and communication have stimulated the growth of international commerce, and on the other hand the opportunities to finalize the contracts electronically such as: fax; e-mail; internet, has eliminated the distance and time factors and has opened new global markets which led to a swell of the volume of international commerce. This study seeks to provide a theoretical and practical treatment of the sales contract through which the ownership right is transferred. Considering the characteristics of such contracts, it is important to treat it in details in order to highlight the its juristic importance as a juristic act; the elements of the sales contract; the characteristics; the conditions of validity; the dissolution, termination and waiver.

\section{Agricultural Contract of Sale of Land and Inconsistencies with the Provisions of Co-ownership}

In the Albanian judicial practice and in the legal framework of the co-ownership of members of agricultural families, we lack a unified practice because of the incompatibility between the dispositions of the Civil Code for the transition of the ownership of agricultural land in the case of co ownership of the agricultural family, law no.7501 dated July $19^{\text {th }} 1991$ "On the Land" and the article 5/c of the law no.8337 dated April 30"th 1998 "On the sale and purchase of the agricultural land, meadow and pastures". The clash between these dispositions resides in the following directions:

First, co owners of the agricultural land became all those members of Albanian families that lived in he villages and were members of agricultural families before the issue of the law no.7501 "On the land". The number of the members of 
the agricultural family and of the persons that would benefit from co-ownership over it was predefined since the law on the land was approved. Yet, the dispositions of the Civil Code on the land, chapter on co-ownership, not only are incoherent with the dispositions of the law, but they also stress out that co-ownership in the agricultural family can be generated from gender, marriage, adoption, being accepted as a member etc (article 222 of the Civil Code). According to this disposition of the Civil Code, the circle of co-owners on the land not only is impossible to define according to the criteria of the law "on the land" but the circle of co-owners can be expanded by giving the opportunity to join in to persons who were born after 1991 when agricultural land was distributed. As a consequence of the incoherence of the dispositions of the Civil Code, chapter of co-ownership (article 222) and the article 5/c of the law "On the sale and purchase of the agricultural land, meadows and pastures, today we do not have a unified civil circulation of the agricultural land in different districts of the country. In the dispositions of the Civil Code, co-ownership as an institution of the right, is created by the willingness of the parties such as in the case of the sales contract or the heritage by testament or by legal ways. In all of these dispositions, the circle of inheritors can't be expanded or decreased a priori from the dispositions of other laws which were made later because one of the main properties of the created juristic relations, is their future stability. The circle of co-owners can be added when they give up part of their co-ownership rights with the purpose to transfer such ownership to other persons through: sales contract, donation, inheritance and exchange. The circle of co-owners can be also decreased when one or some co-owners alter their rights to other co-owners in respect to the right of pre-purchase, provided in the article 204 of the Civil Code. What does not comply with the principles of the Civil Right concerning ownership, is the fact that to the co-owners circle cannot be added other persons to benefit through the dispositions of other laws. As a consequence, the overlapping of the analyzed dispositions, including the dispositions of the Civil Code for the co-ownership of the members of the agricultural family, leads to the instability of the civil juristic relations about the agricultural land. Considering what we stated above, co-owners of an agricultural land will be those subjects that "The law on the land" foresees as beneficiaries of the ownership right in the moment of its issue.

As far as the above is concerned, we recommend the change of the content of the dispositions of the Civil Code, chapter on the co-ownership of the agricultural family, and a part of the dispositions of the law no. 8337 dated April $30^{\text {th }}$ 1988 "O the sale and purchase of the agricultural land, meadows and pastures" which run against the dispositions of the law 7501 dated July $19^{\text {th }} 1991$ "on the land". This law is currently in power. After the year 1998, in the most of the notarial offices, the head of the agricultural family cannot alter the agricultural land that he and the other family members benefited based on the law 7501 "On the land" without previously obtaining an authorization by the competent court. Getting an authorization by the court in the territory of which the agricultural land is situated, means nothing else but making members or new co-owners those persons who were born after August $1^{\text {st }} 1991$. Part of the judges have consented to the request to grant an authorization for alteration of the share belonging to the children born after August $1^{\text {st }} 1991$ based on the dispositions of the Civil Code on the co-ownership of the agricultural family and the article 5/c of the law no. 8337 dated April 30th 1988 "On the sale and purchase of agricultural land, meadows and pastures". Another part of judges have rejected such requests based on the reasoning that they could not issue an authorization for a person who has not benefitted land by the law 7501 "On the land" and consequently, cannot be a co-owner in the agricultural family.

Concerning the solution of such problem, we recommend as necessary the unification of of the judicial practice with a unification decision of the United Colleges of the Supreme Court concerning the different decisions given by the judges for granting authorizations for the alteration of the agricultural land.

\section{The Right of First Refusal as Provided in Law "About the Returning and Compensation of Property"}

Law no 7698, date 15.4.1993 "About the returning and compensation of the property of former owners would consist the first step by which the state would know the right of private property. This legal right was denied for more than 50 years during the communist regime in the Albanian state.(Maho,2009,p.149) This law in the articles 1 and 2 of which, defines the group of subjects as well as its object. According to the article no 1, this law used to know to the former owners or their heirs the right of ownership over the property made public, expropriated, dispossessed, based on the legal articles and decisions which were implemented after the date 29-th November 1944. Whereas in the article 20 of the law no 7698, date 15.4.1993 "About returning and compensating the property of former owners" changed by the law no 7916, date 12.4.1995 it is provided that: "In the territory, agricultural lands or not which are occupied by state buildings such as shops, warehouses, workshops etc,..., the former owners have the right of the first refusal of this property in case of privatization with the price defined by the dispositions in power". Due to this disposition the lawmaker has enormously expanded the concept of the right of first refusal by providing the exercise of the right of first refusal due to the similarity 
of the real estates. Whereas law no. 9235, date 29.7.2004 "About the return and compensation of property" changed by law no.9388, date 4.5.2005 and law no.9583 date 17.7.2006, provides the right of first refusal in the article no.14 which in its first paragraph states that: About the real estates which are occupied by state buildings, the expropriated subjects have the right of first refusal over these objects in case they are privatized". This law, in its 11-th article provides even the ways and methods by which these owners would be compensated.

As far as the article no 21 of the law 7698 date 15.4.1993 is concerned "About the returning and compensating of the property of the former owners" The joint colleges of the Supreme Court have unified the judicial practise by verdict no 23 date 01.04.2002, by reasoning that "The Right of First Refusal of the Former Owners (his/her heirs) known in the article 21 of the law "About the Returning and Compensating of the properties of the former Owners" is considered a real right and as such it can be possessed due to the contract of donation. Real right is considered even the right of compensation for the property that used to belong to former owners but that cannot be returned based on the specification of the law about the return and compensation of the property of former owners. Even the right of compensation of the former owners (their heirs) can be easily exercised by means of donation.

The right of first refusal and the right of compensation of the former owners (their heirs) is included in the concept of the possessions that a person has which in itself involves a wide range of rights not only real but also personal (of obligation).

Article 761 of the Civil Code explicitly defines that the object of the contract of donation can be possessions or real rights over possessions. Whereas, according to the article 705 of the Civil Code, the contract of sale has as its object the passing of ownership or a right by paying a price. By not mentioning the element of refunding which makes a huge difference between these two contracts by making a comparison as far as the object is concerned, it is observed that while the contract of donation is a contract for passing of the possession or rights to the person addressed while the object of the contract of sale nowadays is wider than that. It includes not only the passing of the right over property to the person but also the passing of the other rights that belong to the seller as long as these rights are freely exercised without any restriction provided by law or that derives from their very nature as well as due to their character that is too personal.

While the contract of sale has a consensual nature, the contract of donation is considered as a real contract which means it is considered as signed at the moment in which the possession or real estate, which consists its object, is delivered (article 764 of the Civil Code). However, when the object of the contract of donations is not possessions but other rights over possessions such as shares in joint ownership or other real rights over the possessions of the others, then the contract of donation embodies a consensual nature.

In conclusion, even the contract of the donation of the right of first refusal of the former owner (his/her heirs) as well as that of the donation of the compensation of the possessions which cannot be returned under the conditions of law "About the returning and compensation of the property of former owners", is considered as a consensual right, which means it is considered as signed as long as the donor has expressed his/her will to make the donation in the way required by law and the person to whom the donation is addressed to, has expressed in the same way his/her will to accept the donation.

\section{Conclusions}

Sales is a mutual agreement and as such, it implies mutual obligations for both parties. The entity of rights and obligations of the seller and the buyer form the content of the sales contract. The obligations of the seller consist in the obligation to transfer the ownership right to the buyer, the correct delivery of the merchandise, the warranty from eventual defects, and the guarantee that the buyer will calmly enjoy the purchased item free of any ownership claim of third parties over it. The Civil Code in its attempt to regulate the right of first refusal is not based at all on the Albanian canon right but makes a completely different regulation to it. In the article 204 of the Civil Code are provided the main conditions in order for the right of first refusal to exist. These conditions should be primarily related to the existence of the possession in joint ownership. Secondly, the possession in joint ownership must be real estate. The first refusal is exercised only upon real estate. It is not exercised upon personal belongings and therefore the owner in this case is free to sell his/her part in joint ownership to everybody without being obliged to inform the other joint owners. Thirdly, the alienation of the part from the owner must be made through means of refunding. In cases when the joint owner alienates his/her part without any kind of refund for instance in cases when the right of first refusal is not respected. The article 204 of the Civil Code provides in a summarised way the procedure of the achievement of first refusal.

In relation to the law of the land we recommend the change of the content of the dispositions of the Civil Code, chapter on the co-ownership of the agricultural family, and a part of the dispositions of the law no. 8337 dated April $30^{\text {th }}$ 
1988 "O the sale and purchase of the agricultural land, meadows and pastures" which run against the dispositions of the law 7501 dated July $19^{\text {th }} 1991$ "on the land". This law is currently in power. After the year 1998, in the most of the notarial offices, the head of the agricultural family cannot alter the agricultural land that he and the other family members benefited based on the law 7501 "On the land" without previously obtaining an authorization by the competent court. Getting an authorization by the court in the territory of which the agricultural land is situated, means nothing else but making members or new co-owners those persons who were born after August $1^{\text {st }} 1991$. Concerning the solution of such problem, we recommend as necessary the unification of of the judicial practice with a unification decision of the United Colleges of the Supreme Court concerning the different decisions given by the judges for granting authorizations for the alteration of the agricultural land.

\section{References}

The Civil Code of the Republic of Albania, approved by the law No. 7805, date 29.07.1994, changed by the law No.8536, date 18.10.1999 and No. 878, date 3.05.2001

The Civil Code of the Popular Socialist Party of Albania, approved by the law No. 6340, date 26.06.1981

The Civil Code of the year 1929, Papirus, 2010

Law- No. 7843, date 13.07.1994 "About the registration of the real estates"

Decree no. 2083, date 6.7.1955 " About the property "

The Unified Decision of the Joint Colleges of the Supreme Court, No. 1 date 06.01.2009

The Unified Decision of the Joint Colleges of the Supreme Court No. 10, date 24.03.2004

The decision of the Judicial Court of Law Tirana No. 3917 date 13.05.2001

Dollani Nada, " A series of lectures on the comparative civil right ", EUT, 2010

Maho Besnik, " The gaining of ownership on real estates ", EUT - Press, Tirana, 2009

Pulaha Selami, " The Feudal Ownership in Albanian Properties, XV - XVI century, Tirana, The Science Academy of the PRA, The Institution of History, 1988.

Oliver Jean Schmitt, " The Venedict Arberia, 1392-149 ", Nature, Tirana, 2007

The History of the Albanian State and the State of Right in Albania, Luarasi, Tirana 2011

Wilkes John "The Illirus", Bacchus, Tirana, 2005

Semini Mariana, "The Right of Obligations and of the Contracts", the Particular Part, Scanderbeg books, Tirana, 2010

Shkurti Altin, "The institution of first refusal", Juridical Tribune, 1998

Kondili Valentina, "The Civil right II" the specific part, Geer, 2008

Law no 7698, date 15.4.1993 "About the returning and compensation of the property of former owners" changed by law no 7916 date 12.4.1995

Law no.9235, date 29.7.2004 "About returning and compensation of property" changed by law no. 9388, date 4.5.2005 and law no. 9583, date 17.7.2006

Tahiri Ëngjëllushe, "The Form of the Contract of Sale of the Real Estates and its Importance", July 15, 2011, taken from : http://albanianjustice.com//p=1024 seen for the last time on 7.11.2013 